\title{
Leaching of inorganic carbon and nutrients from rocks of the Arctic archipelagos (Novaya Zemlya and Svalbard)
}

\author{
Alexander Polukhin ${ }^{1}$, Petr Makkaveev $^{1}$, Alexey Miroshnikov ${ }^{2}$, Gennadii Borisenko $^{2}$, and Pavel \\ Khlebopashev $^{1}$
}

Received 1 December 2020; accepted 5 February 2021; published 26 July 2021.

Over the Arctic Ocean, the concentration of nutrients is limiting the development of phytoplankton, and hence the whole ecosystem. The main source of nutrients in the Arctic is river runoff and remineralization. However, there are local features of the functioning of coastal ecosystems, they are associated with the supply of nutrients from the glacier streams. Experiments with samples of rocks (represented by dolomitic shales and limestone) have been conducted to test the hypothesis that the main source of nutrients for coastal ecosystems are the rocks forming the bedrock of glacier streams. Exposure of rock samples in distilled water was held from 5 to 14 days and the content of nutrients has increased. As a result of laboratory experiments, the leaching rates were obtained. The rates are $0.021-0.15 \mathrm{mmol} / \mathrm{m}^{2}$ day and $0.1-2.5 \mathrm{mmol} / \mathrm{m}^{2}$ day for total nitrogen and total inorganic carbon, respectively. The concentration of nutrients $(0.3-33 \mu \mathrm{M}$ of nitrogen, $214-1928 \mu \mathrm{M}$ of total inorganic carbon) in glacial streams confirms this assumption. Field and experimental data show that the glacial runoff from the Arctic archipelagos contains a significant amount of nutrients that can directly affect the activity of coastal ecosystems, making an important contribution to the primary production of the coastal areas in the Arctic. KEYWORDS: Arctic; biogeochemistry; glacial streams; nutrient; weathering.

Citation: Polukhin, Alexander, Petr Makkaveev, Alexey Miroshnikov, Gennadii Borisenko, and Pavel Khlebopashev (2021), Leaching of inorganic carbon and nutrients from rocks of the Arctic archipelagos (Novaya Zemlya and Svalbard), Russ. J. Earth. Sci., 21, ES4002, doi:10.2205/2021ES000758.

\section{Introduction}

In recent years, many studies have been devoted to the study of climate change in the Arctic [Groisman et al., 2017, Mokhov, 2008. There are both regional and local changes in different environments (air, water, soil) which were reported in recent assessments [AMAP, 2013, 2017, 2018. Their main

\footnotetext{
${ }^{1}$ Shirshov Institute of Oceanology RAS, Moscow, Russia

${ }^{2}$ Institute of Geology of Ore Deposits, Petrography, Mineralogy, and Geochemistry RAS, Moscow, Russia

Copyright 2021 by the Geophysical Center RAS. http://rjes.wdcb.ru/doi/2021ES000758-res.html
}

task is to review the current state of the environment, as well as inform the scientific community and the general population about global changes in the Arctic region, and also forecast future changes and their subsequent impact on humans.

The Arctic archipelagos, in particular on the territory of Russia, are studied very poorly, primarily because of its inaccessibility and harsh climatic conditions. Novaya Zemlya Archipelago (NZA) is one of them. There are separate studies on the general geographic description of the archipelago [Boyarsky, 2009]. A number of works devoted to the study of the coastal waters of the archipelago in the Kara Sea were published according to data obtained in the expeditions of the Shirshov Institute of Oceanology, Russian Academy of Sciences 
(SIO RAS) [Amelina et al., 2018. Glukhovets and Goldin, 2018, Stepanova and Nedospasov, 2017. The previous study of the water streams and rocks of the bays of NZA was published in 2013 [Makkaveev et al., 2013 and showed features of the transformation of the chemical composition of water in Blagopoluchiya Bay (NZA). Experiments were carried out with rocks forming the shores of this bay and an assumption was made about the source of mineral nitrogen, carbon and other nutrients for the coastal ecosystem, and the spatial scale of the influence of runoff from NZA was shown.

The Spitsbergen archipelago is studied much better. The first research began more than a century ago; nowadays, all needed research infrastructure is available. International groups consider such problems as the general hydrophysical water structure over the Svalbard, the effect of melting glaciers on the hydrological structure of fjord waters, the features of the water balance of the archipelago, the transfer of allochthonous material by some rivers, the influence of permafrost on coastal areas [Bogen and Bønsnes, 2003. Bogorodskii et al., 2020, Frey et al., 2017, Hagen et al., 2003, Humlum et al., 2003; Killingtveit et al., 2003, Marchenko and Morozov, 2016. Sobota, 2014. Many publications are devoted to the study of the parameters of the carbonate system $(\mathrm{pH}$, partial pressure of carbon dioxide, dissolved carbon in all forms) and the consequences of changes in its equilibrium (acidification) [Fransson et al., 2016, Nomura et al., 2018. Yasunaka et al.,2018 which may affect the biotic components of the archipelago's marine ecosystem [Calosi et al., 2017] Thor et al., 2016. Comprehensive research on Svalbard is carried out by scientists of the Institute of Geophysics of the Polish Academy of Sciences at the Hornsund station, located in the same fjord. Polish scientists are actively exploring the processes occurring on land and affecting the coastal waters due to the transfer of matter by rivers [Rachlewicz et al., 2016. They are conducting investigations of the surface layer of the sea, studying the motion of waters from the archipelago to nearby water areas according to their bio-optical characteristics [Kowalczuk et al., 2017]. Experiments similar to [Makkaveev et al., 2013], but with permafrost, showed the rate of release of nutrients into the water [Pogojeva et al., 2018]. During the CARSIC (https://www.niva.no/en/projectweb/carsic) and
POMPA (https://pompaproject.wordpress.com/) projects (supported by Norwegian Research Council), the effects of ice and melt glacial water on the abiotic characteristics of the ecosystem were studied. Evaluating the results of the research, it can be argued that the influence of the continental runoff was clearly tracked on the hydrochemical structure of the fjord waters not only during warm, but also during cold seasons. Obviously, in the cold period there is a liquid runoff from the shore [Yakushev et al., 2016. Analysis of water from the Murdochelva stream in Templefjord, Svalbard, revealed high values of $\mathrm{Si}(57 \mu \mathrm{M})$ and $\mathrm{NO}_{3}(8.5 \mu \mathrm{M})$ [Polukhin et al., 2016. To compare the results of the experiments with NZA rocks we sampled limestone from the bedrock of the Murdochelva stream and conducted leaching experiments with it as well as with samples from NZA in 2013.

In recent research, it was noted that climate warming in the Arctic might lead to the melting of permafrost and the related consequences (growth in the supply of organic carbon, nutrients, etc.) [Semiletov et al., 2016]. These consequences will cause the activation of biological processes [Docherty et al., 2018] or, in special cases, an increase of the ocean acidification rate [Semiletov et al., 2016. Moreover, the role of nitrogen stored in the bedrock is only poorly understood [Dixon et al., 2012, and it is estimated that up to $20 \%$ of the global nitrogen budget is stored in geologic materials, primarily as ammonia ions and nitrate [Dixon et al., 2012, Holloway and Dahlgren, 1999. Over the Arctic region, nitrate nitrogen is one of the key elements and its concentration is a limiting factor in the evolution of phytoplankton communities in the Arctic seas [Sapozhnikov and Metreveli, 2015. Weathering of terrestrial bedrock might also have an impact on the ecosystem [Docherty et al., 2018.

The main goal of our research is to understand the role of bedrock in the saturation of glacial meltwater with dissolved nutrients. The results of the experiment allowed us to compare the rate of emission of silicate, phosphorus, nitrogen, and carbon into the water of the streams in NZA and Svalbard. Unfortunately, there are no reliable instrumental estimates of the volume of glacial flow, however, taking into account the increase in air temperature in the Arctic [Groisman et al., 2017, Overland et al., 2008, decrease in ice cover [AMAP, 2017, Wang and Overland, 2012 it can be assumed that 


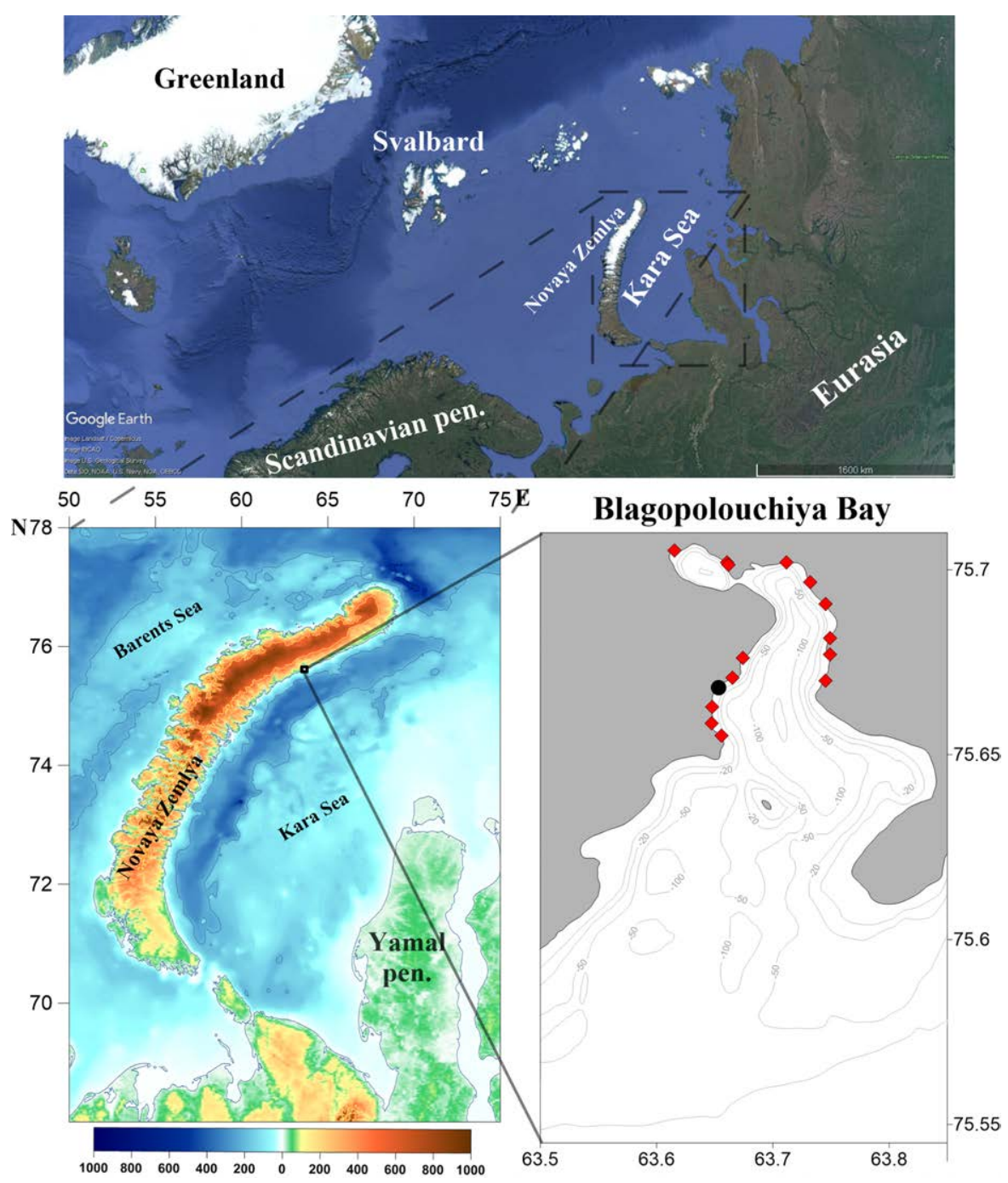

Figure 1. Blagopoluchiya Bay in the Kara Sea, NZA. Black dot shows the site of rock sampling, red diamonds show locations of water samples from streams (September 2014-2016).

the runoff from the Arctic islands (including the underground) will increase. Along with the runoff, the supply of nutrients will also increase, which can lead to changes in the environmental parameters of the Arctic ecosystems.

\section{Materials and Methods}

\subsection{Study Site \& Sampling}

Blagopoluchiya Bay is located on the Northern Island of NZA and is washed by the waters of the Kara Sea (Figure 1).
The radiation balance over the year is less than $5 \mathrm{kkal} / \mathrm{cm}^{2}$, annual precipitation is in the range 200-300 $\mathrm{mm}$ and the average air temperature in July is $+2-4^{\circ} \mathrm{C}$ [Pavlov and Lebedeva, 2016. The area of the Nalli Glacier, the nearest to the sampling site, belonging to the Northern Ice Cap, is $343 \mathrm{~km}^{2}$, and its elevation is $750 \mathrm{~m}$ a.s.l. [Boyarsky, 2009 .

Investigations of the streams in Blagopoluchiya Bay were conducted in September 2007 (9 samples), 2013 (4 samples), 2014 (4 samples) and in early August 2016 ( 7 samples). In the bay there are two permanent (in the warm period of the year) streams (1 and 2 in Figure 2 ) and several temporary streams $(3,4$, and 5 in Figure 2 . The sam- 

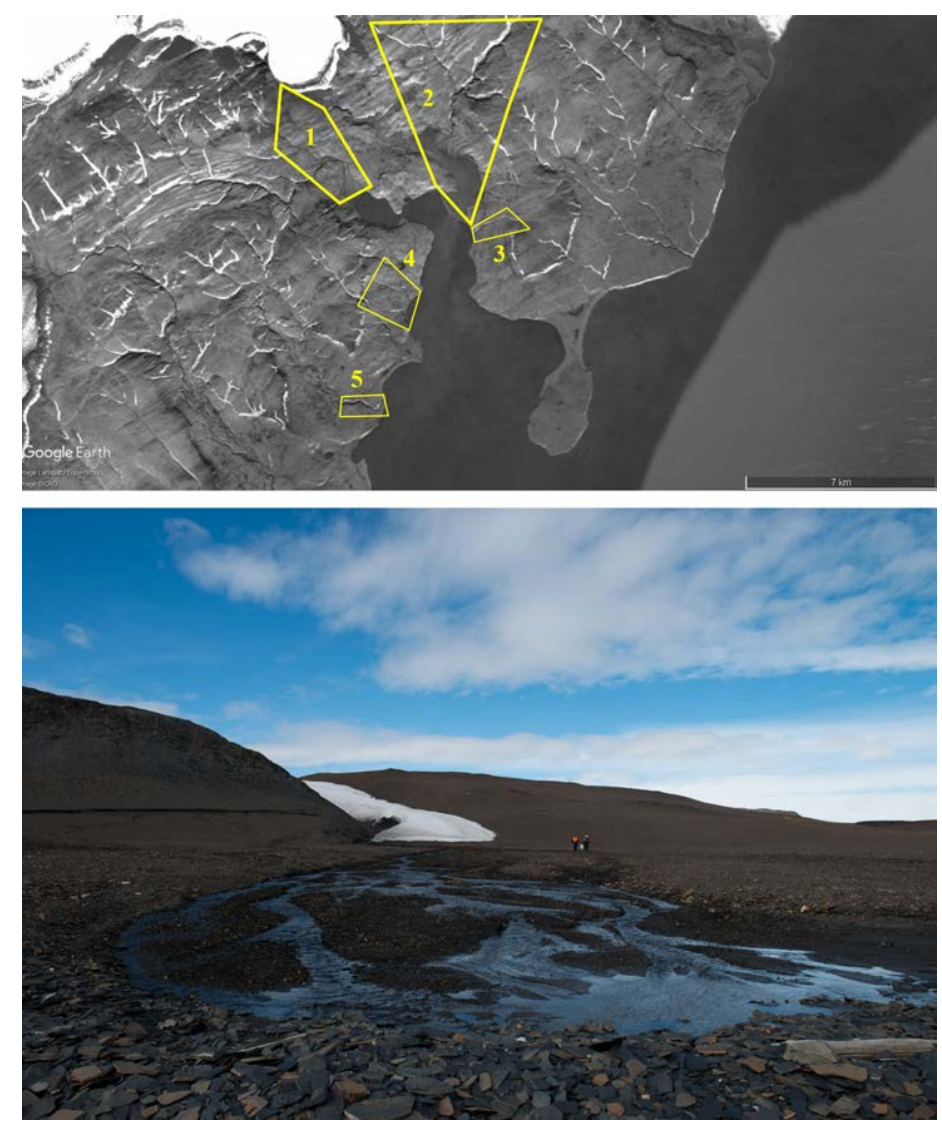

Figure 2. Typical stream of glacial origin, Blagopoluchiya Bay, Novaya Zemlya, 02.08.2016.

pling was conducted in a short distance from the stream mouth without influence of seawater (controlled by conductometer). A typical description of a sampling site is as follows: "A stream flowing from under the snowfield. The flow is fast, the water is transparent. At the place of sampling, flows come through a heap of shale and sand of black colour." (Figure 2). Air temperature usually was above $0^{\circ} \mathrm{C}$, and sometimes it was rainy during the landings. Rocks from NZA have been sampled during expeditions to the Kara Sea in 2014 [Flint and Poyarkov, 2015. The most common type of rock is dolomitic siltstone. During the sampling the rocks were divided by colour: black $(A c)$ and brown $(A s)$. Laboratory studies have clarified its classification and chemical composition (see Results).

The study site in Svalbard was located in the Tempelfjorden on the West Spitzbergen Island shelf (Figure 3). It is $14 \mathrm{~km}$ long, $5 \mathrm{~km}$ wide and has an area of $57 \mathrm{~km}^{2}$ [Fransson et al., 2015]. Average air temperature in June, at the time of the expeditions, is $+3.4^{\circ} \mathrm{C}$, with precipitation at $18 \mathrm{~mm}$ ("The Norwegian Meteorological Institute," n.d.).
There are two drainage basins around the area, the northern basin covers an area of $745 \mathrm{~km}^{2}$ and has a glacial coverage of $58 \%$ [Hagen et al., 1993 . Calving tidewater glacier Tunabreen is located in the inner part of Templfjorden [Fransson et al., 2015. The biggest stream here is Murdochelva, originating from Murdochbreen glacier. Sampling of rock material was conducted in the Murdochelva bedrock and the sample is performed by a dolomitic limestone.

\subsection{Methods and Leaching Experimental Study}

Water samples from streams as well as for experimental studies from the bucket (see below) have been collected into $0.5 \mathrm{l}$ and $0.25 \mathrm{l}$ polyethylene bottles respectively. Samples have been filtered through 0.45-micron filters (Millipore) manually. Analysis have been conducted as soon as possible after sampling (but not exceeded 6 hours). The $\mathrm{pH}$ value was determined on the ionomer "Ekoniks Ex- 


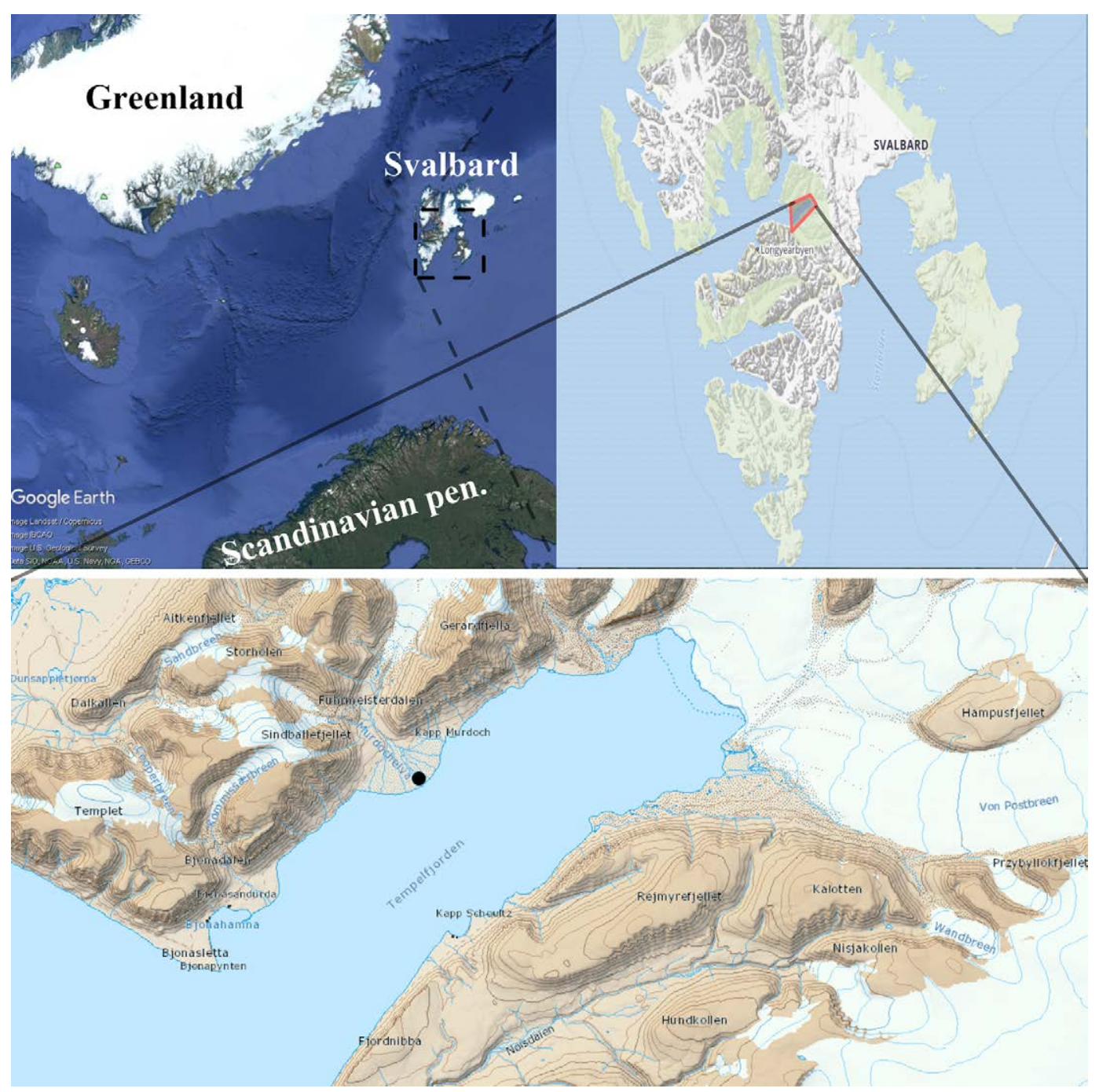

Figure 3. Tempelfjorden in Western Spitzbergen Island, Svalbard. Black dot shows the site of rock sampling, Murdochelva valley (June, 2017).

pert 001" with a glass composite $\mathrm{pH}$ electrode by CJSC "Akvilon" (Moscow, Russia). For calibration we used buffer solutions ISO 8.135-74 (methods of research are the same as in [Dickson, 1993]). Analysis of Alk was conducted by direct titration (using the Bruyevich method) with a visual determination of the titration end point [Pavlov et al., 2008. The calculation of dissolved inorganic carbon (DIC) was carried out using the pH-Alk method [Grasshoff et al., 2009, Millero, 1995] with the CO2sys program [Lewis and Wallace, 1998]. Determination of phosphates $\left(\mathrm{PO}_{4}\right)$ was conducted using Murphy-Riley method, silicate ( $\mathrm{Si}$ ) by Mullin and Riley method, ammonia nitrogen $\left(\mathrm{NH}_{4}\right)$ by Sagi-Solorzano method, nitrites $\left(\mathrm{NO}_{2}\right)$ by Bendschneider and Robinson, nitrates $\left(\mathrm{NO}_{3}\right)$ by Morris and Riley with modifications suggested by Grasshoff and Wood [Parsons, 2013]. Analysis of total phosphorus (TIP) and nitrogen (TIN) have been performed using techniques by Valderrama [Valderrama, 1981 (we have used autoclave instead of stainless-steel pressure cooker).

The mineralogy was determined using a combination of microscopy and X-ray diffraction (XRD) with a Rigaku D/Max 12200 diffractometer. The chemical composition of the rock samples was studied by X-ray fluorescence analysis using a sequential wavelength spectrometer with wavelength dispersion, model PW 2400 (Philips Analytical).

The experiments with leaching of the elements from the rock into distilled water were conducted for the first time in 2012 [Makkaveev et al., 2013 
under laboratory conditions. The samples of rocks (dolomitic siltstone) were placed into polyethylene buckets containing 3 litres of distilled water (values of $\mathrm{PO}_{4}, \mathrm{Si}, \mathrm{NH}_{4}, \mathrm{NO}_{2}, \mathrm{NO}_{3}$, TIP, TIN, and DIC were close to $0, \mathrm{pH}=7$ ). The samples of dolomitic siltstone were plates from 0.7 to $0.9 \mathrm{~cm}$ thick and from 111.6 to $393.9 \mathrm{~g}$ in mass. To prevent microbial activity, the samples were treated with a mercuric chloride solution $(0.3 \mathrm{~g} / \mathrm{L})$ and sterilized with UV irradiation for $15 \mathrm{~min}$ from each side. The exposure lasted for three weeks at a temperature of $20^{\circ} \mathrm{C}$ in the laboratory. Water samples (needed for analysis, usually $250 \mathrm{ml}$ ) were collected once a week, and the content of the phosphates, the silicates, the nitrate, the nitrite and total nitrogen, the $\mathrm{pH}$ value and the total alkalinity was determined.

Further experiments were conducted during the expeditions on board the vessel (in 2014, 2016 and 2017) and these were carried out with the samples (mainly $A c$ sample and dolomitic limestone from Svalbard) in a closed transparent polyethylene bucket filled with 3 litres of distilled water on the open deck in conditions close to natural (outside temperature, natural illumination). To prevent microbial activity, the samples were treated with a mercuric chloride solution $(0.3 \mathrm{~g} / \mathrm{L})$. Experiments on board of the vessel were performed in duplicate, which allowed us to estimate the error associated with the method. After the results were obtained, we calculated the rates of leaching of the investigated parameters into the distilled water. First, we measured concentrations in micromoles per litre, and then transferred the values to micromoles per square meter, having previously measured the square surface of each rock sample. The obtained values were recalculated per day, depending on the duration of the experiment (from 5 to 10 days).

\section{Results}

\subsection{Hydrochemistry of Glacial Streams}

According to the data, we can state that hydrochemical characteristics are highly variable. For example, the $\mathrm{pH}$ during the campaign of 2016 varied from 8.01 to 9.35 NBS scale units and over the entire period of investigation it varied from 7.8 to 9.35 NBS scale units. The lowest Alk was observed in
$2014(904 \mu \mathrm{M})$ and the highest in $2013(4473 \mu \mathrm{M})$. It is interesting to note that the highest Alk value observed at site BSh_1 belongs to a stream in the north-western part of the bay. We have repeatedly taken samples from that stream in different years and have never otherwise observed such a high value $(1688 \mu \mathrm{M}$ in $2007,2615 \mu \mathrm{M}$ in 2014 , $2225 \mu \mathrm{M}$ in 2016). The reason for this could be the low speed of the stream and the long distance covered by the stream from the glacier $(2.5-3.0 \mathrm{~km})$ and even under the glacier's body. Thus, the only reason for the high amount of inorganic carbon in the water is leaching from the rocks. The same process is related to the nitrogen. The range of $\mathrm{NO}_{3}+\mathrm{NO}_{2}$ in all investigated streams was from 0.63 to $11.17 \mu \mathrm{M}$ (Table 1), and the variability from stream to stream varied greatly during one sampling campaign (from 0.98 to 8.8 in 2007 for the same meteorological conditions and underlying surface layer). If we subtract all the mineral nitrogen from the total nitrogen, we see that the organic nitrogen predominates in the samples. During the expeditions in 2013 and 2014 we also observed high concentrations $(<1 \mu \mathrm{M})$ of ammonia nitrogen in all studied streams (Table 1). Concentration of dissolved silicate varied from 5 to $50 \mu \mathrm{M}$ over the entire observation period (Table 1). The median value was $28.6 \mu \mathrm{M}$ and this is quite a high concentration for small glacial streams [Hodson et al., 2002, 2005. Keller et al., 2010. An explanation can be found in the chemical composition of the samples of dolomitic shales; in both the $A c$ and As samples, $\mathrm{SiO}_{2}$ prevails in the composition $(70 \%$ and $30 \%$ respectively, see subsection 3.2 ). Concentration of mineral phosphorus $\left(\mathrm{PO}_{4}\right)$ in the water of the streams was not high, only in 3 samples out of 23 did it exceed $1 \mu \mathrm{M}$ (Table 1).

\subsection{Geology and Mineralogy of Blagopoluchiya Bay, NZA}

The shores of the Blagopoluchiya Bay, where the dolomitic shales were sampled, are composed of (Figure 4):

- argillites, aleurolites, sandstones with interbeds of limestones, silicates and dolomites of the Middle-Upper Carbonic period, Kruglovskaya suite (C2-3kr);

- argillites, aleurolites and silicates with interbeds of cherty-rhodochositic rocks of Up- 
Table 1. Hydrochemical Properties of Streams in the Blagopoluchiya Bay, Novaya Zemlya

\begin{tabular}{|c|c|c|c|c|c|c|c|c|c|c|}
\hline $\begin{array}{l}\text { Sampling } \\
\text { site }\end{array}$ & Date & $\begin{array}{c}\mathrm{pH} \\
\text { NBS }\end{array}$ & $\begin{array}{c}\text { Alk } \\
\mu \mathrm{M} / 1\end{array}$ & $\begin{array}{l}\mathrm{PO}_{4} \\
\mu \mathrm{M} / 1\end{array}$ & $\begin{array}{l}\text { TIP } \\
\mu \mathrm{M} / 1\end{array}$ & $\begin{array}{c}\mathrm{Si} \\
\mu \mathrm{M} / 1\end{array}$ & $\begin{array}{c}\mathrm{NO}_{3}+\mathrm{NO}_{2} \\
\mu \mathrm{M} / \mathrm{l}\end{array}$ & $\begin{array}{l}\mathrm{NH}_{4} \\
\mathrm{\mu M} / 1\end{array}$ & $\begin{array}{c}\text { TIN } \\
\mu \mathrm{M} / 1\end{array}$ & $\begin{array}{c}\mathrm{DIC} \\
\mu \mathrm{M} / 1\end{array}$ \\
\hline 1.1 & 15.09 .2007 & 7.84 & 1688 & 1.19 & 1.6 & 29.06 & 0.98 & & 196.05 & \\
\hline 2.1 & 15.09 .2007 & 8.18 & 2685 & 0.97 & 1.34 & 50.17 & 4.33 & & 80.64 & \\
\hline 3 & 15.09 .2007 & 8.3 & 1874 & 0.09 & 0.25 & 28.57 & 8.84 & & 66.81 & \\
\hline 4.1 & 16.09 .2007 & 8.33 & 1694 & 0.04 & 0.25 & 31.5 & & & 63.3 & \\
\hline 5.1 & 16.09 .2007 & 8.2 & 1859 & 0.07 & 0.28 & 27.03 & 5.83 & & 14.38 & \\
\hline 6.2 & 16.09 .2007 & 8.09 & 1697 & 0.22 & & 32.69 & 1.81 & & & \\
\hline 7.1 & 16.09 .2007 & 8.24 & 1620 & 0.16 & 0.29 & 22.24 & 2.78 & & & \\
\hline 8.1 & 17.09 .2007 & 8.54 & 3539 & 0 & & 40.48 & 3.78 & & & \\
\hline 9.1 & 17.09 .2007 & 8.45 & 1739 & 0.14 & & 29.43 & 5.91 & & & \\
\hline BSh_1 & 15.09 .2013 & 7.8 & 4473 & 0.02 & 0.39 & 42.44 & 3.64 & 5.34 & 81.35 & 4815.8 \\
\hline BSh_2 & 15.09 .2013 & 8.62 & 736 & 0.04 & 0.18 & 6.41 & 3.04 & 2.29 & 78.93 & 732.2 \\
\hline BSh_7 & 16.09 .2013 & 8.22 & 2148 & 0 & 0.2 & 38.33 & 4.48 & 1.28 & 99.33 & 2205.7 \\
\hline BSh_9 & 16.09 .2013 & 8.31 & 2472 & 0.03 & 0.29 & 37.94 & & 1.58 & 143.64 & 2522.1 \\
\hline b1-1 & 30.08 .2014 & 8.09 & 2615 & 0.5 & & 13.86 & 8.24 & 2.32 & & 2673.0 \\
\hline b3-1 & 30.08 .2014 & 7.98 & 2189 & 1.53 & & 9.14 & 4.31 & 1.54 & & 2255.1 \\
\hline b4-1 & 30.08 .2014 & 8.2 & 904 & 1.16 & & 7.93 & 3.34 & 3.26 & & 916.4 \\
\hline b5-1 & 30.08 .2014 & 8.17 & 1741 & 0.56 & & 26.84 & 5.5 & 2.23 & & 1768.6 \\
\hline B1 & 2.08 .2016 & 9.35 & 544 & 0.09 & 0.33 & 5.34 & 1.91 & 0.28 & 28.85 & 517.0 \\
\hline B2 & 2.08 .2016 & 8.48 & 1411 & 0.04 & 0.08 & 26.62 & 3.8 & 0.13 & 40.4 & 1418.8 \\
\hline B3 & 2.08 .2016 & 8.54 & 1741 & 0.06 & 0.12 & 24.54 & 4.58 & 0.13 & 40.13 & 1749.4 \\
\hline B4 & 2.08 .2016 & 8.59 & 2203 & 0.02 & 0.05 & 36.74 & 6.98 & 0.08 & 27.09 & 2201.3 \\
\hline B5 & 2.08 .2016 & 8.52 & 2088 & 0.06 & 0.15 & 32.48 & 11.17 & 0.08 & 62.07 & 2099.7 \\
\hline B7 & 4.08 .2016 & 8.01 & 2225 & 0.12 & 0.22 & 18.68 & 0.63 & 0.11 & 25.44 & 2312.6 \\
\hline
\end{tabular}

Alk - total alkalinity, $\mathrm{PO}_{4}$ is mineral phosphorus, TIP is total inorganic phosphorus, Si is dissolved silicate, $\mathrm{NO}_{3}+\mathrm{NO}_{2}$ is sum of nitrates and nitrites nitrogen, $\mathrm{NH}_{4}$ is ammonia nitrogen, TIN is total inorganic nitrogen, DIC is dissolved inorganic carbon.

per Carbonic-Lower Permian, Medvezhinskaya suite (C3-P1md);

- shales, argillites and argillaceous sandstones of Lower Permian, Tsivolkinskaya suite (P1cv) [VSEGEI, 2006].

The soils in this part of NZA are developed weakly [Krupskaya et al., 2017]. We thus suggested that the main source of mineral nitrogen was the rocks, mostly dolomitic shales that form elevations and the coastline of Blagopoluchiya Bay. The sample named $A c$ is represented by ankeritolite shale with carbonaceous matter according to the microscopy data (Figure 5).

The rock consists of thin microcrystalline interlayers of quartz enriched with carbonaceous matter and interlayers with a pelite structure composed of quartz and ankerite.
Sericite and feldspar are noted as insignificant admixtures in these interlayers. The texture is slate, banded. The schistosity is well emphasized by the carbonaceous substance, which is observed in the form of subparallel clusters (Figure $5 \mathrm{a})$. In association with carbonaceous substance, pyrite is found. These interlayers containing carbonaceous particles have a microcrystalline structure and a pelitomorphic structure. Along these interbeds, the shale splits into fairly thin plates.

The banded texture is also expressed in the development of interlayers with different size and quantitative ratio of grains of ankerite and quartz (Figure 5b). The ankerite formula $-\mathrm{Ca}\left(\mathrm{Mg}, \mathrm{Fe}^{2+}\right)$ $\left[\mathrm{CO}_{3}\right]_{2}$. Interlayers with a grain size of 0.01 to $0.03 \mathrm{~mm}$ contain ankerite of $15-20 \%$, and in interlayers with a grain size of $0.02-0.06 \mathrm{~mm}$, the amount of ankerite is up to $30 \%$. The structure of interlayers is pelitic. 


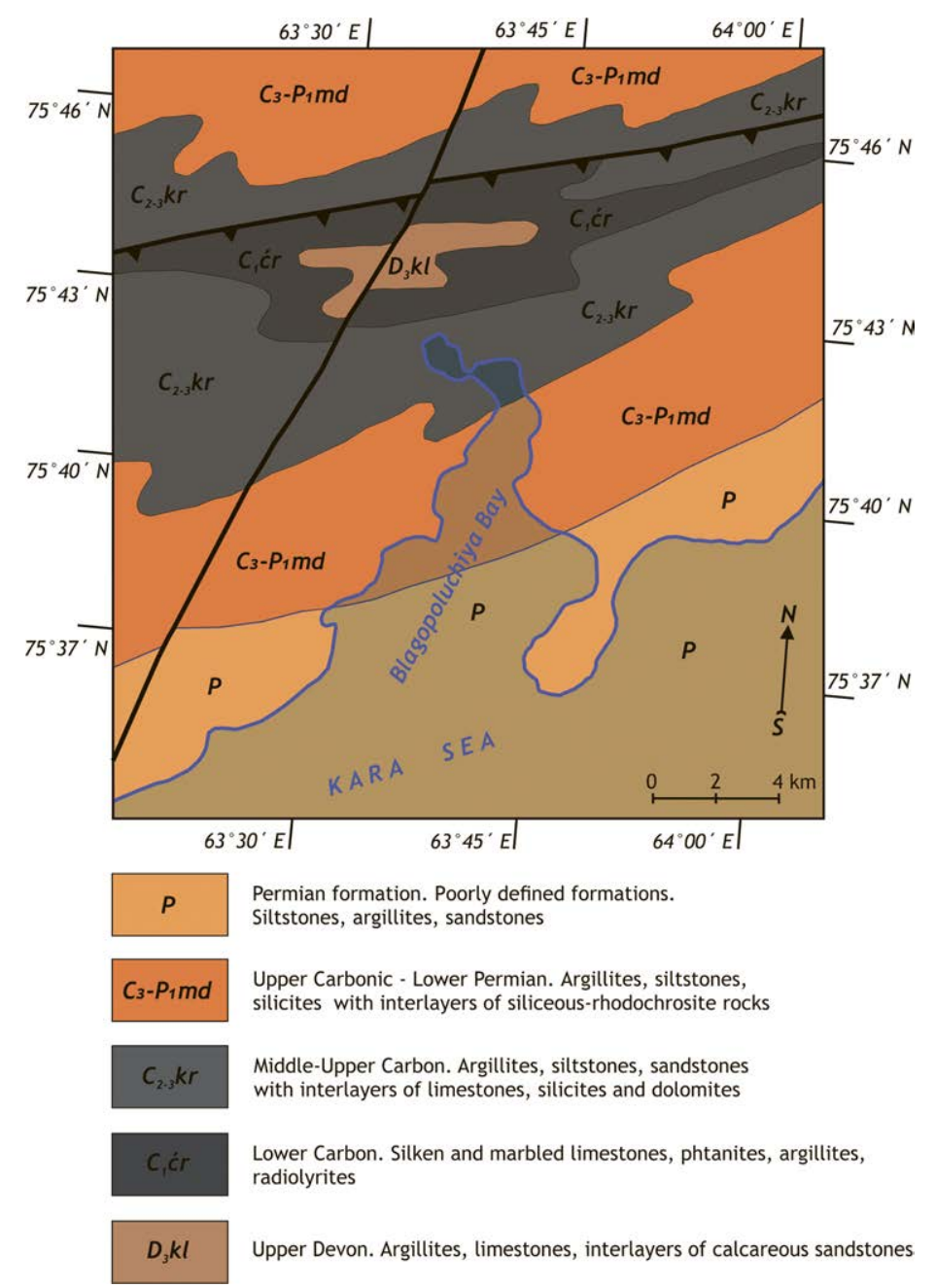

Figure 4. Geological map of Blagopoluchiya Bay, NZA.
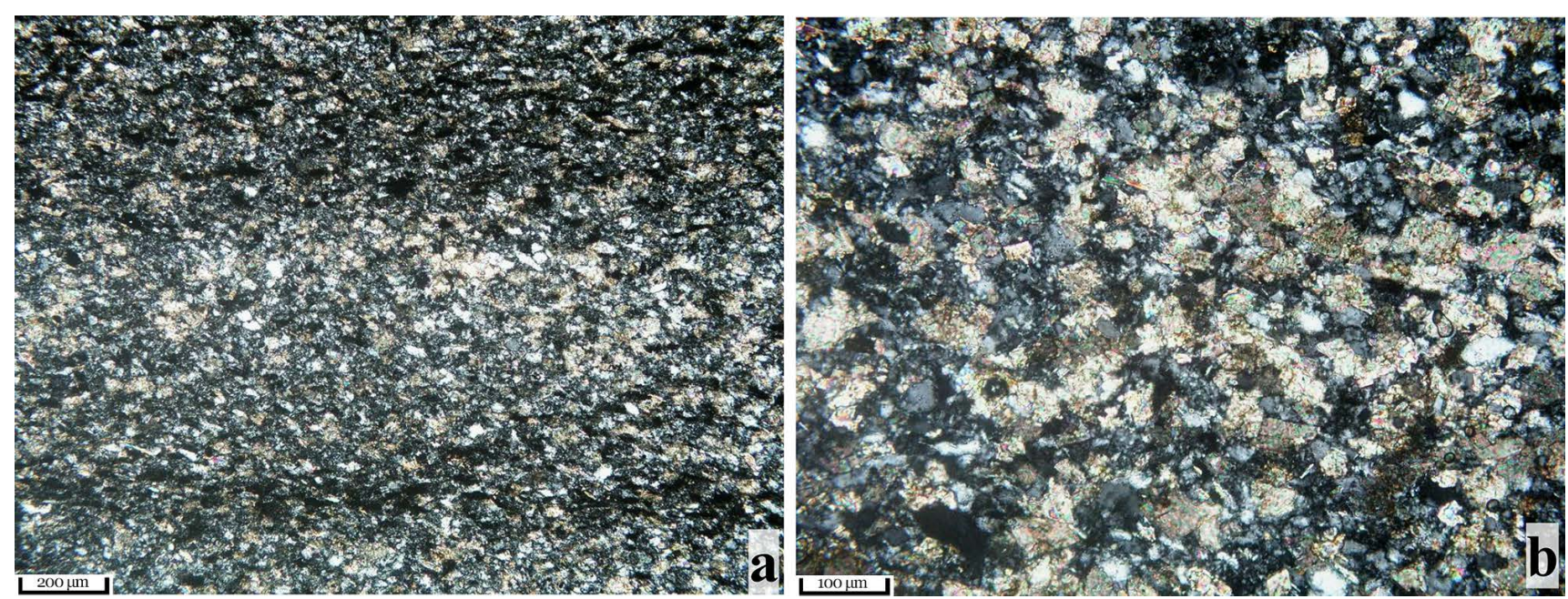

Figure 5. Ankeritolite shale with carbonaceous matter. Microphoto with the analyzer (a); detailed structure of interlayers of pelite grains (size $0.02-0.06 \mathrm{~mm}$ ) of quartz and ankerite (b). 

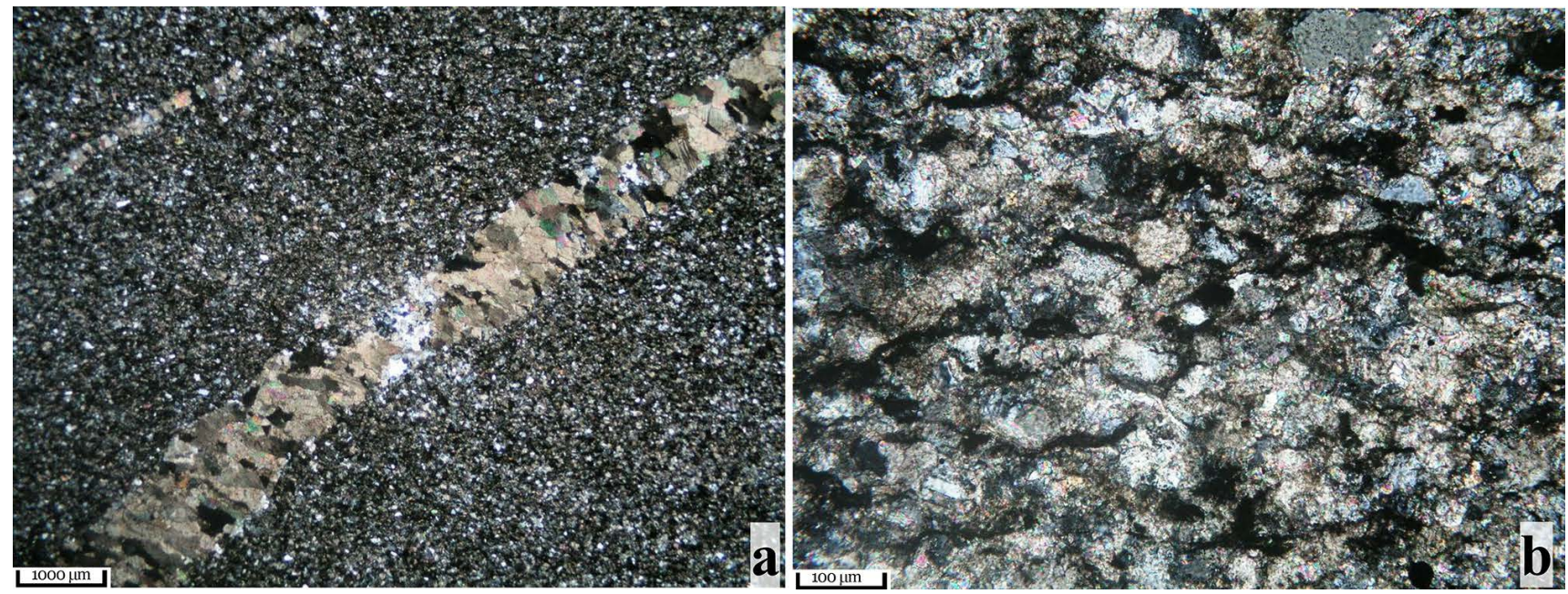

Figure 6. Sandy ankeritolite with a vein of ankerite. Microphoto with the analyzer (a); detailed structure of sandy ankeritolite. Black is carbonaceous substance (b).

Table 2. Chemical Composition of Rock Samples According to X-ray Fluorescence Analysis, Mass\%

\begin{tabular}{lccccccccccc}
\hline Rock sample & $\mathrm{Na}_{2} \mathrm{O}$ & $\mathrm{MgO}$ & $\mathrm{Al}_{2} \mathrm{O}_{3}$ & $\mathrm{SiO}_{2}$ & $\mathrm{~K}{ }_{2} \mathrm{O}$ & $\mathrm{CaO}$ & $\mathrm{TiO}_{2}$ & $\mathrm{MnO}$ & $\mathrm{Fe}_{2} \mathrm{O}_{3}$ & $\mathrm{P}_{2} \mathrm{O}_{5}$ & $\mathrm{SO}_{3}$ \\
\hline Dolomitic shales $(A c)$ & 0.75 & 2.88 & 7.67 & 69.7 & 1.48 & 3.48 & 0.56 & 0.24 & 6.72 & 0.07 & 0.49 \\
Dolomitic shales $(A s)$ & 2.53 & 6.90 & 5.82 & 30.40 & 0.73 & 20.24 & 0.52 & 0.77 & 9.56 & 0.10 & 0.12 \\
Dolomite limestone & 0.13 & 5.88 & 1.42 & 10.07 & 0.39 & 39.64 & 0.12 & 0.010 & 0.86 & 0.03 & 1.43 \\
\hline
\end{tabular}

The sample named $A s$ is represented by sandy ankeritolite shale according to the microscopy data (Figure 6).

The chemical analysis showed that samples of As contained more than $26 \%$ of $\mathrm{CaCO}_{3}$ and about $0.5 \%$ of organic carbon; in the sample of $A c$, the $\mathrm{CaCO}_{3}$ content was only $0.4 \%$ and that of organic carbon was more than 1\%. According to X-ray fluorescence analysis, the carbonates proportion in the sample is up to $40 \%$ (see Table 2).

The rock sample from Svalbard, Tempelfjorden, is dolomite limestone with fragmentare-oolotic structure. The texture is massive. An essential part of the rock is ooliths of round or elongated shape with a concentric-shell and radial-radiant structure. There are fragments of shells (Figure 7). The cementing mass is represented by a microcrystalline carbonate with areas of more crystallized fine-grained calcite with dolomite. In the limestone composition, there are grains of clastic quartz (more than $0.15 \mathrm{~mm}$ ), which is corroded by dolomite. As a micro impurity, pyrite is present, which is partially oxidized with the formation of iron oxide developed in cement. The presence of calcite and dolomite in the rock composition is confirmed by data of X-ray phase analysis.

\subsection{Leaching Experiment: Performance \& Results}

First experiments in 2012 were conducted under laboratory conditions $\left(20^{\circ} \mathrm{C}\right.$ air temperature, artificial lighting) with an exposure time of 3 weeks, water from the bucket was sampled once a week [Makkaveev et al., 2013]. Results of analysis have been averaged over three measurements and revealed that the leach of TIC was more intensive from $A s$ while $A c$ was leaching more TIP. Weathering of TIN was slightly higher for $A c$ and the sum of nitrites and nitrates was slightly higher for $A s$. Leaching of Si from $A s$ prevailed from $A c$ although $\mathrm{SiO}_{2}$ compound was dominant in $A c$ (Table 3).

In 2014, the leaching experiment was repeated with $A c$ and $A s$ close to in situ conditions in terms of temperature and illumination. Exposure time was 9 days, bottles with rock samples were installed on the open deck of the vessel. Weathering 
values of Si $\left(0.41-0.43 \mathrm{mg} / \mathrm{m}^{2}\right.$ day and $0.44-0.46$ $\mathrm{mg} / \mathrm{m}^{2}$ day respectively) and nitrogen $\left(0.17 \mathrm{mg} / \mathrm{m}^{2}\right.$ day and $0.11 \mathrm{mg} / \mathrm{m}^{2}$ day respectively) did not differ for $A c$ and $A s$. Leaching of phosphorus was lower from $A c$ and TIC; it was two times more intense from $A c$ than from $A s$. Generally, for both samples, the leaching of nitrogen, phosphorus, and silicate was low (Table 3).

In 2016, only samples of the $A c$ type were used for the experiment. The first piece of rock $(A c 1)$ was sampled from the beach near the mouth of the stream where it was constantly in contact with water. The second $(A c 2)$ was sampled from an elevation of a few kilometers from the shore where the rock could not be exposed to the water. Thus, we exclude the influence of seawater on the shore with high waves, storms, and tides and affecting the rocks. For the sample $A c$ we observed elevated emissions of mineral $\mathrm{P}$ and $\mathrm{NO}_{3}+\mathrm{NO}_{2}(0.06-0.08$ $\mathrm{mg} / \mathrm{m}^{2}$ day and $0.18 \mathrm{mg} / \mathrm{m}^{2}$ day, respectively) relative to $A c 2\left(0.02-0.04 \mathrm{mg} / \mathrm{m}^{2}\right.$ day and 0.04 $\mathrm{mg} / \mathrm{m}^{2}$ day, respectively). Leaching of Si was the same $\left(0.18\right.$ and $0.24 \mathrm{mg} / \mathrm{m}^{2}$ day $)$. Weathering of TIP, TIN and TIC was higher from the sample $A c 2$ than Ac1 (Table 3). As a result, we conclude that the rocks, which have never been in constant contact with water (except precipitation), flowing from the elevations above Blagopoluchiya Bay seem to be the main source of organic forms of phosphorus and nitrogen and inorganic carbon. We state that the rocks are the main source of organic $\mathrm{P}$ and $\mathrm{N}$ owing to the fact that difference in content of total and mineral forms of $\mathrm{P}$ and $\mathrm{N}$ is presented with the organic part of the elements.

In the framework of the POMPA project in 2015 and 2017, samples of water and rocks (limestone) from the bottom of the Murdochelva stream flowing into the Tempelfjord (Figure 1) were sampled for comparison of the environment of the different Arctic islands. High contents of nitrates (5.07$8.57 \mu \mathrm{M})$, Si $(45.9-57.5 \mu \mathrm{M})$ and DIC $(833 \mu \mathrm{M})$ were observed in the water of Murdochelva. The experiment (exposure 5 days, in situ conditions) with the leaching of two samples of the limestone revealed that the weathering of $\mathrm{Si}$ was higher than from the NZA rocks $\left(0.76-2.08 \mathrm{mg} / \mathrm{m}^{2}\right.$ day $), \mathrm{PO}_{4}$ was at the same level $\left(0.04 \mathrm{mg} / \mathrm{m}^{2}\right.$ day $)$ and TIP was also slightly higher $\left(0.4-0.46 \mathrm{mg} / \mathrm{m}^{2}\right.$ day $)$.
We also observed a high rate of leaching of nitrogen from the Svalbard limestone $\left(4.8 \mathrm{mg} / \mathrm{m}^{2}\right.$ day for TIN and $0.7 \mathrm{mg} / \mathrm{m}^{2}$ day for $\left.\mathrm{NO}_{2}+\mathrm{NO}_{3}\right)$. Leaching of DIC, in general, showed a similar speed in comparison with dolomite shales from NZA.

\section{Discussion}

During several expeditions to the Kara Sea, we managed to obtain data on the concentrations of nutrients in the streams of Blagopoluchiya Bay (NZA). We understand that all of them are of the glacial origin. Several streams had high values of Si $(5-50 \mu \mathrm{M})$ and $\mathrm{NO}_{3}(0.6-11 \mu \mathrm{M})$ and the very high content of such nutrients as silicates or nitrates in the small streams of the Arctic should not be surprising and have also been observed in Greenland recently [Docherty et al., 2018. Soil and permafrost are the main pools of nitrogen and organic carbon [Dixon et al., 2012, Rachlewicz et al., 2016 but on Northern Island of NZA they are absent due to the severe climate. Thus, the bedrock and dolomitic shales that are widely spread over NZA are the main sources of dissolved nutrients in the glacial streams [Dixon, 2016]. The same process has been observed in the Templfjorden, Svalbard: high values of dissolved silicates, nitrates and DIC in the Murdochelva stream water. Bedrock of the stream is limestone, the chemical compound of which consists mainly of $\mathrm{CaO}$ and $\mathrm{SiO}_{2}$. In Billefjorden, which is located to the north of Templfjorden, [Rachlewicz et al., 2016 high amounts of carbonates and some nutrients were observed, the chemical composition of the water of the stream is the same as in the bedrock. We can state that glacial melt water is leaching the bedrock owing to its quite low $\mathrm{pH}$ and low mineralization [Rachlewicz et al., 2016. Moreover, we believe that the difference in the chemical compositions of streams in the same catchment area could be connected with a difference in the type of feed of the streams. Concentration of nutrients could be higher in those glacialfed streams that are also additionally fed from the groundwater (relevant only during the warm season). According to the estimates by Russian glaciologists from the Institute of Geography RAS (Moscow) [Glazovsky and Lavrentiev, 2018, the total mean frontal ablation from the three investigated glaciers of NZA to the Kara Sea is $0.4 \mathrm{~km}^{3} / \mathrm{a}$. 

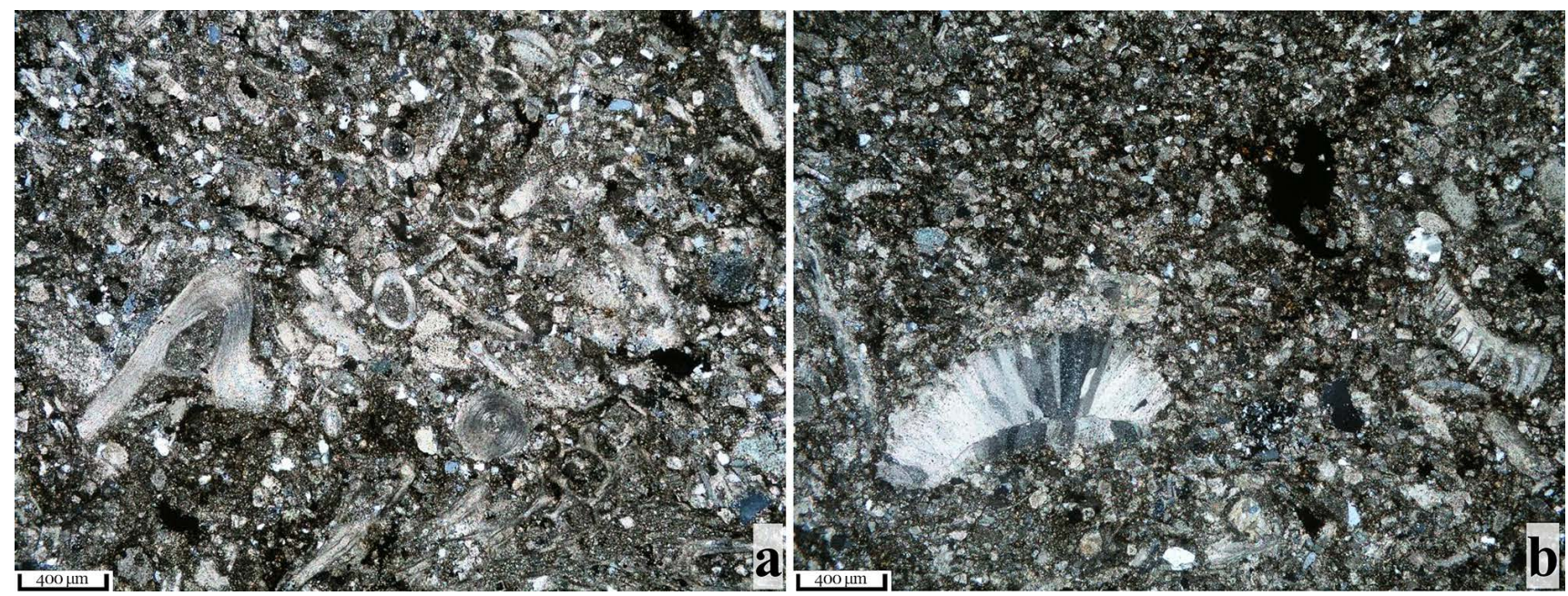

Figure 7. Dolomitized limestone with clastic-oolitic structure. Microphoto with the analyzer.

From all of the Kara Sea shore of NZA it could reach $1 \mathrm{~km}^{3} / \mathrm{a}$ and even more. Such a small amount of freshwater (in comparison with the total continental discharge to the Kara Sea, $1200-1400 \mathrm{~km}^{3} / \mathrm{a}$ [Osadchiev et al., 2017] with a high concentration of nutrients (Table 1) could become an important source for coastal ecosystems of NZA. The same conclusions can be stated for the Svalbard coastal area (Tempelfjorden).

Experimental studies of rock samples from NZA and Svalbard have also revealed interesting results. For example, leaching of silicates occurs more intensely at high temperatures $\left(20^{\circ} \mathrm{C}\right.$ in laboratory) than at low temperatures (close to $0^{\circ}$ in high latitude Arctic region in late summer period). Leaching of phosphorus from all types of rock samples happens with the same speed if we compare the results of experimental studies. Judging by the difference of TIP and mineral $\mathrm{P}$, the main part of phosphorus belongs to the organic part. The same can be stated for nitrogen, wherein limestone from Svalbard emits more of it than shales from NZA. There is a high leaching rate of DIC at in situ conditions (low temperatures) for all types of rock. We also consider an important result of experiments with the same type of rock (from NZ): one sampled near the stream on the seashore, another sampled several $\mathrm{km}$ from the coast. The results show that, from the second sample, leaching of organic phosphorus and nitrogen is occurring more intensely, as well as that of DIC. Thus, it is very important to consider features of the bedrock layout for investigation of the transport of nutrients in the high Arctic. This conclusion could be confirmed by A. Beylich who discussed fluxes of matter in the Arctic environment and geomorphological processes [Beylich, 2012], specific to the cold-climate catchment systems. Besides that, the results obtained of our investigation could complement the state-of-the-art knowledge of the dynamics and consumption of nutrients in high latitude Arctic streams during the warm season as well as active biological processes with the availability or absence of different nutrients [Docherty et al., 2018 .

\section{Conclusions}

Rocks containing nitrogen are widely distributed along the shores of the islands of the Arctic basin and their role in the nitrogen cycle is underestimated due to a lack of data [Dixon et al., 2012. Holloway and Dahlgren, 2002. As a result of this work, for the first time, the data revealed the rate of leaching of chemical elements from the rocks forming the shores of NZA and Svalbard. Streams and small rivers flowing from glacierized mountains of both archipelagos in warm period absorb nitrogen and carbon (as well as other nutrients) into the water and supply them to the coastal water. Similar processes of the removal of organic matter occur in Greenland and may affect the coastal carbon system [Pain et al., 2020]. This finding may be important for exploring the Arctic ecosystems. The fact 
Table 3. Results of Leaching Experiments, $\mathrm{mg} / \mathrm{m}^{2}$ day

\begin{tabular}{|c|c|c|c|c|c|c|}
\hline & $\mathrm{Si}$ & TIP & $\mathrm{PO}_{4}$ & TIN & $\mathrm{NO}_{2}+\mathrm{NO}_{3}$ & DIC \\
\hline \multicolumn{7}{|c|}{ 2012. Exposure 7-21 days*, $T \sim 20^{\circ} \mathrm{C}$} \\
\hline$A c$ & $0.39-1.25$ & $0.22-0.53$ & $0.01-0.02$ & $0.70-2.14$ & $0.11-0.17$ & $1.53-4.02$ \\
\hline As & $1.12-1.15$ & $0.13-0.17$ & $0.02-0.03$ & $1.02-1.05$ & $0.31-0.37$ & $3.21-4.33$ \\
\hline
\end{tabular}

2014. Exposure 9 days, $T$ in situ

\begin{tabular}{lcccc}
\hline Ac & $0.41-0.43$ & 0.01 & 0.17 & 20.3 \\
As & $0.44-0.46$ & $0.05-0.06$ & 0.11 & 8.2 \\
\hline
\end{tabular}

2016. Exposure 12 days, $T$ in situ

\begin{tabular}{lllllll}
\hline$A c 1$ & 0.16 & $0.16-0.08$ & $0.06-0.08$ & $0.34-0.38$ & 0.18 & 17.4 \\
$A c 2$ & 0.24 & $0.36-0.38$ & $0.02-0.04$ & $1.72-2.02$ & 0.04 & 35.0 \\
\hline
\end{tabular}

2017. Exposure 5 days, $T$ in situ

\begin{tabular}{|c|c|c|c|c|c|c|}
\hline limestone & $0.76-2.08$ & $0.40-0.46$ & 0.04 & $4.74-4.90$ & $0.64-0.76$ & $22.4-25.8$ \\
\hline
\end{tabular}

is that mineral nitrogen is an important component for the development of phytoplankton communities and can limit their growth [Docherty et al., 2018 . Sapozhnikov and Metreveli, 2015. Previously, the flow of chemical elements from the Arctic islands was not taken into account in assessing potential primary production. We assume that leaching of nitrogen and other nutrients can also occur in other Arctic archipelagos. Thus, a considerable quantity of nutrients entering the waters of the Arctic seas and the Arctic Ocean are unaccounted. Nutrients transported into the coastal water area are important for the formation of primary production in these waters. Although the existence of this source is possible only during a limited period of the summer when there is a deficit of nutrients in the surface waters.

In this work, we have not taken into account crucial geomorphologic processes [Dixon et al., 2016] influencing on the transport of dissolved and suspended matter in the conditions of glacial coverage of the territory. It is also important to understand the trends of the air temperature throughout the year as well as long-term trends during changing climate in the Arctic region [Groisman et al., 2017, Rachlewicz et al., 2016. Unfortunately, the research area on NZA is very difficult to access and is open to study only for the very short warm season. Therefore, the results are very important in the study ecosystem changes at high latitudes.

Funding. This work was supported by the State Agreement of The Ministry of Science and Education of Russian Federation (theme \# 01282021-0016 and theme \# 121041500216-3); by the Russian Foundation for Basic Research projects \# 18-05-60246 (processing geochemistry samples) and 18-05-60069 (processing hydrochemistry data); by the Grant of the President of the Russian Federation for state support of young Russian scientists - candidates of science, research project MK860.2020.5 (processing carbonate chemistry data); by the Research Council of Norway project 246752 "POMPA - Pollutants and carbonate system parameters in polar environment media: snow-ice- 
seawater-sediments-coastal discharge" (https://po mpaproject.wordpress.com).

Acknowledgments. This work is dedicated to prof. P. N. Makkaveev, who was the head of the Laboratory of Biohydrochemistry at the Shirshov Institute of Oceanology for 20 years. He passed away on 23 May 2020, due to CoVid-19 pandemic. He was the author of the concept of nutrient flow from the Arctic islands and its role in the Arctic ecosystems. His colleagues and students will remember with gratitude the time spent with him in the expeditions and in the laboratory. We would like to thank Academician M. V. Flint for organizing expeditions to the Kara Sea and Novaya Zemlya and the opportunity to work in the Arctic. We also thank Dr. Sci. E. Yakushev from NIVA, Norway, for organizing Norwegian-Russian investigations on Svalbard. We are grateful to Dr. Sci. E. G. Morozov for proofreading the English language and anonymous reviewers for comments that helped improve the work.

\section{References}

AMAP (2013), AMAP Assessment 2013: Arctic Ocean Acidification. Arctic Monitoring and Assessment Programme, viii + 99 pp. AMAP, Oslo, Norway.

AMAP (2017), Snow, Water, Ice and Permafrost in the Arctic (SWIPA) 201\%. Arctic Monitoring and Assessment Programme, xiv + 269 pp. AMAP, Oslo, Norway.

AMAP (2018), AMAP Assessment 2018: Arctic Ocean Acidification. Arctic Monitoring and Assessment Programme, vi + 187 pp. AMAP, Troms $\varnothing$, Norway.

Amelina, A. B., A. V. Drits, et al. (2018), Zooplankton in Bays of the Novaya Zemlya Archipelago: Composition, Distribution, and Role in Phytoplankton Grazing and Biosedimentation, Oceanology, 58, No. 6, 825-837, Crossref

Beylich, A. (2012), Major controls of mass transfers and relief development in four cold-climate catchment systems in eastern Iceland, Swedish Lapland and Finnish Lapland: Synthesis paper, Abstracts and Proceedings of the Geological Society of Norway p. 86-123, Geological Society, Norway.

Bogen, J., T. E. Bønsnes (2003), Erosion and sediment transport in High Arctic rivers, Svalbard, Polar Research, 22, No. 2, 175-189, Crossref

Bogorodskii, P. V., N. E. Demidov, et al. (2020), Growth of landfast ice and its thermal interaction with bottom sediments in the Braganzavågen Gulf (West Spitsbergen), Russ. J. Earth Sci., 20, ES6005, Crossref
Boyarsky, P. V. (2009), Islands and Archipelagoes of the Russian Arctic. Novaya Zemlya, Paulsen, Moscow. (in Russian)

Calosi, P., J. E. Søreide, et al. (2017), Contrasting physiological responses to future ocean acidification among Arctic copepod populations, Global Change Biology, 24, No. 1, e365-e377, Crossref

Dickson, A. G. (1993), The measurement of sea water pH, Mar. Chem., 131-142, Crossref

Dixon, J. C. (2016), Contemporary solute and sedimentary fluxes in Arctic and subarctic environments: Current knowledge, Source-to-Sink Fluxes in Undisturbed Cold Environments, 39-51, Crossref

Dixon, J. C., S. W. Campbell, B. Durham (2012), Geologic nitrogen and climate change in the geochemical budget of Kärkevagge, Swedish Lapland, Geomorphology, 167-168, Crossref

Docherty, C. L., T. Riis, et al. (2018), Nutrient uptake controls and limitation dynamics in northeast Greenland streams, Polar Research, 37, No. 1, Crossref

Flint, M. V., S. G. Poyarkov (2015), Comprehensive research on the Kara Sea ecosystem (128th Cruise of Research Vessel Professor Shtokman), Oceanology, 55, No. 4, 657-659, Crossref

Fransson, A., M. Chierici, et al. (2015), Effect of glacial drainage water on the $\mathrm{CO}_{2}$ system and ocean acidification state in an Arctic tidewater-glacier fjord during two contrasting years, Journal of Geophysical Research: Oceans, 120, 2413-2429, Crossref

Fransson, A., M. Chierici, et al. (2016), Late winter-to-summer change in ocean acidification state in Kongsfjorden, with implications for calcifying organisms, Polar Biology, 39, No. 10, 1841-1857, Crossref

Frey, D. I., A. N. Novigatsky, et al. (2017), Water structure and currents in the Bear Island Trough in July-August 2017, Russ. J. Earth Sci., 17, ES3003, Crossref

Glazovsky, A., I. Lavrentiev (2018), Ice Thickness and Frontal Ablation of Nine Outlet Glaciers on Novaya Zemlya, POLAR 2018: Where the Poles come together - Abstract Proceedings. A. Schilling Hoyle (ed.) p. 1109, SCAR, Cambridge. (https://www. scar.org/library/conferences/scar-open-science-confer ences/abstracts/5075-polar2018-abstracts/)

Glukhovets, D. I., Y. A. Goldin (2018), ScienceDirect Surface layer desalination of the bays on the east coast of Novaya Zemlya identified by shipboard and satellite data, Oceanologia, 6, No. 1, 68-77, Crossref

Grasshoff, K., K. Kremling, M. Ehrhardt (2009), Methods of Seawater Analysis, 632 pp. John Wiley \& Sons, US.

Groisman, P., H. Shugart, D. Kicklighter, G. Henebry, N. Tchebakova, et al. (2017), Northern Eurasia Future Initiative (NEFI): facing the challenges and pathways of global change in the twenty-first century, Progress in Earth and Planetary Science, 4, No. 1, Crossref 
Hagen, J. O., O. Liestøl, et al. (1993), Glacier Atlas of Svalbard and Jan Mayen (Vol. 129), 141 pp. Norsk Polarinstitutt, Oslo.

Hagen, J. O., J. Kohler, et al. (2003), Glaciers in Svalbard: Mass balance, runoff and freshwater flux, Polar Research, 22, No. 2, 145-159, Crossref

Hodson, A., M. Tranter, et al. (2002), The hydrochemistry of Bayelva, a high Arctic proglacial stream in Svalbard, Journal of Hydrology, 25\%, No. 1-4, 91-114, Crossref

Hodson, A. J., P. N. Mumford, et al. (2005), The High Arctic glacial ecosystem: new insights from nutrient budgets, Biogeochemistry, 72, No. 2, 233256, Crossref

Holloway, J. M., R. A. Dahlgren (1999), Geologic nitrogen in terrestrial biogeochemical cycling, Geology, 27, 567-570, Crossref

Holloway, J. M., R. A. Dahlgren (2002), Nitrogen in rock: Occurrences and biogeochemical implications, Global Biogeochemical Cycles, 16, No. 4, 65-1-65-17, Crossref

Humlum, O., A. Instanes, J. L. Sollid (2003), Permafrost in Svalbard: A review of research history, climatic background and engineering challenges, Polar Research, 22, No. 2, 191-215, Crossref

Keller, K., J. D. Blum, G. W. Kling (2010), Stream geochemistry as an indicator of increasing permafrost thaw depth in an arctic watershed, Chemical Geology, 273, No. 1-2, 76-81, Crossref

Killingtveit, A, L. Pettersson, K. Sand (2003), Water balance investigations in Svalbard, Polar Research, 22, No. 2, 161-174, Crossref

Kowalczuk, P., J. Meler, et al. (2017), Bio-optical properties of Arctic drift ice and surface waters north of Svalbard from winter to spring, Journal of Geophysical Research: Oceans, 122, No. 6, 4634-4660, Crossref

Krupskaya, V. V., A. Y. Miroshnikov, et al. (2017), Mineral composition of soils and bottom sediments in bays of Novaya Zemlya, Oceanology, 51, No. 1, 215-221, Crossref

Lewis, E. R., D. W. R. Wallace (1998), Environmental System Science Data Infrastructure for a Virtual Ecosystem, Program developed for $\mathrm{CO}_{2}$ system calculations (No.: CDIAC-105) Carbon Dioxide Information Analysis Center, Tennessee, US. Crossref

Makkaveev, P. N., A. A. Polukhin, P. V. Khlebopashev (2013), The surface runoff of nutrients from the coasts of Blagopoluchiya bay of the Novaya Zemlya Archipelago, Oceanology, 53, No. 5, 539-546, Crossref

Marchenko, A. V., E. G. Morozov (2016), Surface manifestations of the waves in the ocean covered with ice, Russ. J. Earth Sci., 16, ES1001, Crossref

Millero, F. J. (1995), Thermodynamics of the carbon dioxide system in the oceans, Geochimica et Cosmochimica Acta, 59, No. 4, 661-677, Crossref

Mokhov, I. I. (2008), Possible regional consequences of global climate changes, Russ. J. Earth. Sci., 10, ES6005, Crossref
Nomura, D., M. A. Granskog, et al. (2018), $\mathrm{CO}_{2}$ flux over young and snow-covered Arctic pack ice in winter and spring, Biogeosciences, 15, No. 11, 3331-3343. Crossref

Osadchiev, A. A., A. S. Izhitskiy, et al. (2017), Structure of the buoyant plume formed by $\mathrm{Ob}$ and Yenisei river discharge in the southern part of the Kara Sea during summer and autumn, Journal of Geophysical Research: Oceans, 122, No. 7, Crossref

Overland, J. E., M. Wang, S. Salo (2008), The recent Arctic warm period, Tellus, Series A: Dynamic Meteorology and Oceanography, Crossref

Pain, A. J., J. B. Martin, et al. (2020), Differences in the Quantity and Quality of Organic Matter Exported From Greenlandic Glacial and Deglaciated Watersheds, Global Biogeochem., 34, No. 10, 1-20, Crossref

Parsons, T. R. (2013), A Manual of Chemical $\&$ Biological Methods for Seawater Analysis, 188 pp. Elsevier, US.

Pavlov, V. A., E. S. Lebedeva, (Eds.) (2016), Kara Sea. Ecological Atlas, Arctic Res. Center, Moscow.

Pavlova, G. Y., P. Y. Tishchenko, et al. (2008), Intercalibration of Bruevich's method to determine the total alkalinity in seawater, Oceanology, 48, No. 3, 438-443, Crossref

Pogojeva, M., E. Yakushev, et al. (2018), Experimental study of the influence of thawing permafrost on the chemical properties of sea water, Rus. J. Earth Sci., 18, No. 5, Crossref

Polukhin, A., E. Yakushev, et al. (2016), Influence of melting glaciers on hydrochemical structure of coastal ecosystem of Western Spitzbergen, Proceedings of International Conference "Managing risks to coastal regions and communities in a changing world" (EMECS'11 - SeaCoasts XXVI) RIOR Publ., Moscow. Crossref

Rachlewicz, G., G. Szpikowska, et al. (2016), Solute and particulate fluxes in catchments in Spitsbergen, Source-to-Sink Fluxes in Undisturbed Cold Environments p. 116-132, University Press, Cambridge.

Sapozhnikov, V. V., M. P. Metreveli (2015), The stoichiometric model of organic matter is the basis for a quantitative study of the production-destruction processes in the ocean, Trudy VNIRO, 155, 135145. (in Russian)

Semiletov, I., I. Pipko, et al. (2016), Acidification of East Siberian Arctic Shelf waters through addition of freshwater and terrestrial carbon, Nature Geoscience, 9, No. 5, 361-365, Crossref

Sobota, I. (2014), Changes in dynamics and runoff from the High Arctic glacial catchment of Waldemarbreen, Svalbard, Geomorphology, 212, 16-27, Crossref

Stepanova, S. V., A. A. Nedospasov (2017), Features of Hydrophysical and Hydrochemical Conditions in Blagopoluchiya Bay (Novaya Zemlya Archipelago), Oceanology, 57, No. 1, 65-74, Crossref 
Thor, P., A. Bailey, et al. (2016), Seawater pH Predicted for the Year 2100 Affects the Metabolic Response to Feeding in Copepodites of the Arctic Copepod Calanus glacialis, PLoS One, 11, No. 12, 1-14, Crossref

Valderrama, J. C. (1981), The simultaneous analysis of total nitrogen and total phosphorus in natural waters, Marine Chemistry, 109-122, Crossref

Wang, M., J. E. Overland (2012), A sea ice free summer Arctic within 30 years: An update from CMIP5 models, Geophysical Research Letters, Crossref

VSEGEI (2006), State Geological Map of the Russian Federation. Scale 1:1,000,000, VSEGEI, St. Petersburg.
Yakushev, E. V., P. N. Makkaveev, et al. (2016), Hydrochemical studies in coastal waters of the Spitsbergen Archipelago in 2014-2015, Oceanology, 56, No. 5, Crossref

Yasunaka, S., E. Siswanto, et al. (2018), Arctic Ocean $\mathrm{CO}_{2}$ uptake: An improved multiyear estimate of the air - sea $\mathrm{CO}_{2}$ flux incorporating chlorophyll a concentrations, Biogeosciences, 15, 1643-1661, Crossref

Corresponding author:

Alexander Polukhin, Shirshov Institute of Oceanology, Russian Academy of Sciences, 36 Nakhimovskii prospect, 117997 Moscow, Russia. (polukhin@ocean.ru) 